\title{
Therapeutic Trial Report on Long-Acting Sulphonamide Ro 4-4393 (Fanasil) in the Treatment of Leprosy
}

\author{
M. L. GAIND, G. V. MENOR and RAMAKRISHNA*
}

\section{INTRODUGTION}

The results obtained with sulphadimethoxine, $\uparrow$ a long-acting sulphonamide in the treatment of leprosy were encouraging in a large number, so impressive in a few cases, (Gaind and Soli r 964) that we decided to undertake another clinical trial with a newer long-acting Sulphonamide Ro 4-43 93, $\ddagger$ supplied to us by Roche Products Limited, Bombay. The antibacterial activity of this sulphonamide is equal or superior to that of other sulphonamides and its retention in the human body is markedly more prolonged than any other known sulphonamide (Garcia Herrera, E. I 964, Tschudi Madsen, S. I 964). Because of this property and of our previous encouraging results with Madribon, we felt that the present drug may even be more effective.

Several preliminary reports of clinical improvement in patients with lepromatous and tuberculoid leprosy have been published, bacteriological improvement has been observed by many workers. Recently Opromolla obtained excellent results in 12 out of the 17 cases, (Opromolla et al. i 964). Barclay et al. (1963) reported good results in 14 patients who completed two years treatment. Ghosh and Chakraborty, (I964) found marked improvement in all the cases of tuberculoid leprosy and marked changes in the morphology of the bacillus and reduction in the bacteriological index in 6 cases of lepromatous leprosy.

The present communication reports a clinical trial in 34 patients of leprosy conducted from March I 963 to December I 964 at the Military Hospital, Poona.

\section{MATERIAL AND METHODS}

Thirty-four leprosy patients, I 7 lepromatous and I 7 tuberculoid, with diagnosis established by clinical, bacteriological and histopathological examinations were selected for this therapeutic trial.

\section{Lepromatous leprosy}

I 7 patients were divided into two groups:

A) those who have had no treatment before the trial

(I 3 patients)

B) those who were having sulphones for a period from 5 months to 2 years and in whom the disease appeared to have become clinically static and were showing no reduction in their bacteriological index (4 patients)

\section{Tuberculoid leprosy}

I 7 patients were divided into two groups.

A) I4 patients who have had no antileprosy treatment before the trial.

B) Three patients who had been having sulphone treatment for a period of 4-6 months and in whom a drug resistance appeared to have developed.

\section{Dosage}

A trial dose of half tablet (o.25 g.) was given to the lepromatous patients once a week for two weeks and thereafter gradually and cautiously increased to a maximum of 3 tablets $(\mathrm{I} \cdot 5 \mathrm{~g}$.) a week. At the time of compiling our results, we observed that most of these patients had remained on 2 tablets ( 1 g.) a week for the major portion of the duration of the treatment. The tuberculoid patients received an initial dose of I tablet for the first week. This dose was

\footnotetext{
* Military Hospital, Wanorie, Poona, I

†Madribon 'Roche'

†Fanasil 'Roche'
} 
rapidly increased to a maximum of 3 tablets ( 15 g.) once a week and maintained at this level during the major portion of the treatment period.

\section{RESULTS AND GOMMENTS}

\section{Lepromatous leprosy}

The results are summarised in Table I.

TABLE I

\section{Iepromatous Leprosy}

Patient No. I-with 122 days duration and 24 g. sulphonamide total dose. There was clinical improvement in 6 to 8 weeks in the form of complete disappearance of erythema and infiltration and considerable bacterial improvement in 8 to io weeks to negativity.

Patient No. 2- had a duration of 210 days and was given $40 \mathrm{~g}$. sulphonamide. In evolution there was an absence of pigmentation, and infiltration regressed to disappearance of some patches completely. There was favourable bacterial evolution.

Patient No. 3-there was lepra reaction with DDS and sulphonamides.

Patient No. 4-duration was 218 days and $42 \mathrm{~g}$. total dose was given. During evolution most of the hypopigmented patches disappeared; sensation returned in the areas previously anaesthetic. When sulphonamide was stopped bacterial reversal occurred.

Patient No. 5-duration was 244 days and total sulphonamide dose $48 \mathrm{~g}$. In evolution pigmentation appeared in hypopigmented patches and anaesthesia improved in some patches.

Patient No. 6- duration of 358 days and total dose of sulphonamide $65 \mathrm{~g}$. All lepromata flattened markedly, and in certain areas the infiltration completely disappeared to leave wrinkled and atrophic skin. Bacterial reversal when the sulphonamide was stopped.

Patient No. 7-duration was 213 days and total dose $36 \mathrm{~g}$. Infiltration regressed; reaction with 3 tablets, but on 2 tablets a week there was no reaction.

Patient No. 8--the duration was $2 \mathrm{I} 4$ days and the total dose $43 \mathrm{~g}$. There was marked regression in infiltration and flattening of nodules. There was bacterial reversal also when the sulphonamide was stopped.

Patient No. 9- the duration was I 26 days and the total dose $4^{\mathrm{I}} \mathrm{g}$. The infiltration regressed greatly.

Patient No. Io-the duration was I 88 days and the total dose $39 \mathrm{~g}$. There was partial regression of infiltration.
Patient No. I I - the duration was I 83 days and the total dose $36 \mathrm{~g}$. All the infiltrative patches disappeared but there was no effect on the macular patches.

Patient No. 12-the duration was I 53 days and the total dose $30 \mathrm{gm}$. The infiltrative patches on the face disappeared, leaving wrinkled skin behind. There was no effect on macular patches.

Patient No. I3-duration was Io9 days and the total dose of sulphonamide $19 \mathrm{~g}$. The patches noticeably flattened and the erythema reduced.

Patient No. 14-the duration was 124 days and the total dose $20 \mathrm{~g}$. There was partial regression of infiltration and return of sensation in some anaesthetic patches. There was bacterial reversal when the sulphonamide was stopped.

Patient No. I5-Duration was 90 days and total dose I $5 \mathrm{~g}$. The patient was previously on sulphones for 2 years. Lepra reaction developed after I tablet DDS. There was marked flattening of infiltrative patches: nasal blockage and nerve tenderness disappeared.

Patient No. I6-the patient when given sulphetrone or sulphonamide i tablet 3 times a week developed lepra reaction but did not on i tablet once a week. Some nodular dwellings on the face disappeared completely and there was marked reduction generally. Some of the patches became hyperpigmented.

Patient No. 17-Erythema nodosum leprosum reaction appeared with DDS, Sulphetrone, and sulphonamide.

N.B. Patients 2, I5, I6, \& I 7 belong to group B.

\section{Group A}

Clinically ro patients showed excellent results. Erythema and infiltration started regressing in $12-16$ weeks, nerve tenderness was reduced in $5^{-6}$ weeks but the thickening persisted till the end of the trial. In 3 patients the improvement was spectacular (see figures I to 9), all infiltrative patches disappeared in $5 \frac{1}{2}$ months and became bacteriologically negative in $3 \frac{1}{2}$ months and remained negative for 3 months before they were discharged. In one patient lepromata flattened out considerably in most of the areas leaving behind wrinkled skin in 6 months when he became near negative bacteriologically; the condition deteriorated within a month, when Sulphonamide was replaced by Sulphetrone, and he started improving again in 6 weeks after reinstituting Sulphonamide and showed a remarkable clinical improvement in 


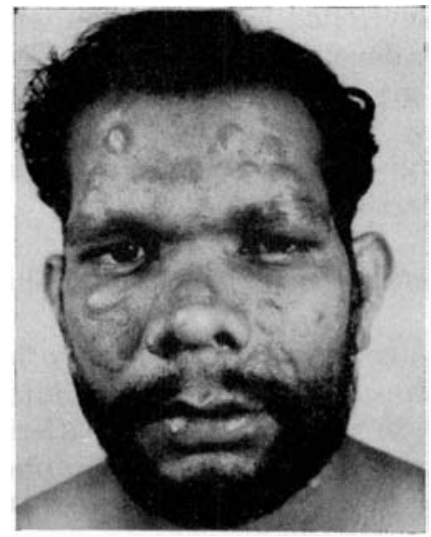

FIG. I

Leprosy Lepromatous before treatment.

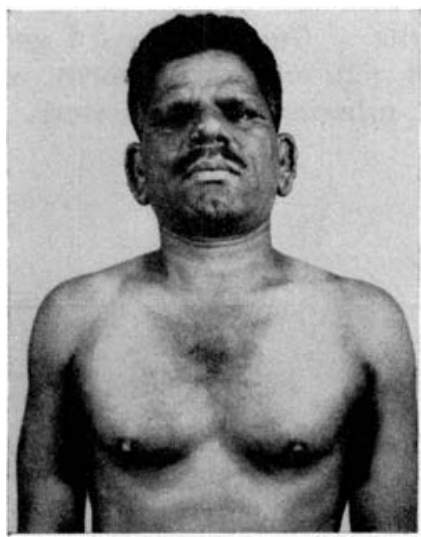

FIG. 4

Leprosy Lepromatous bef ore treatment

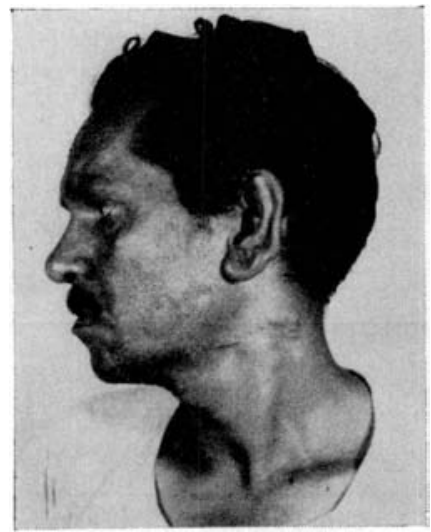

FIG. 7

Leprosy Lepromatous before treatment.

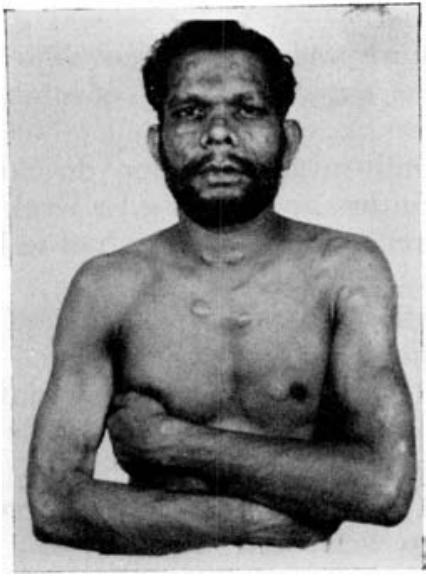

FIG. 2

Leprosy Lepromatous before treatment.

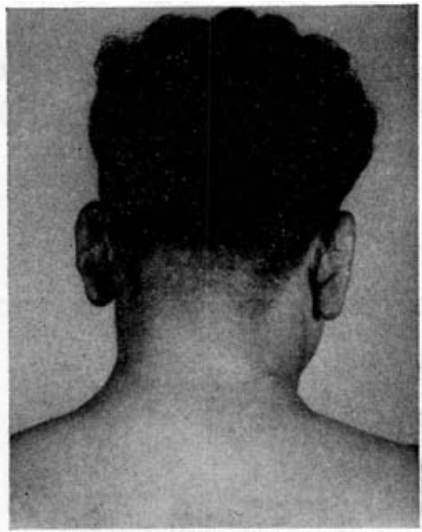

FIG 5.

Leprosy Lepromatous I 2 weeks af ter treatment.

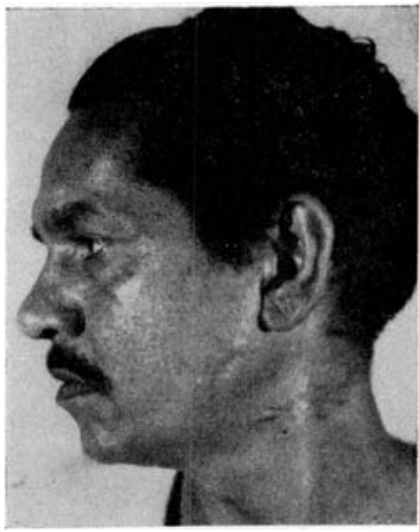

Fig. 8

Leprosy Lepromatous I I weeks after treatment.

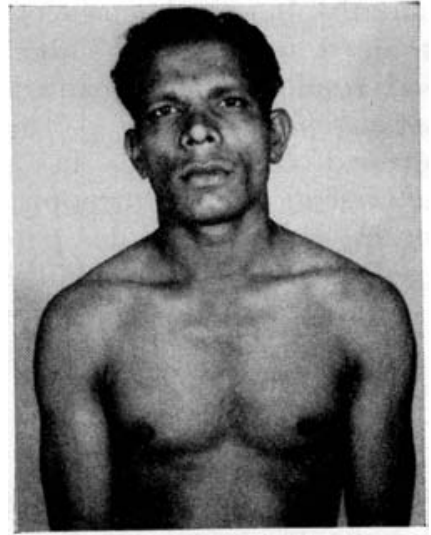

FIG. 3

Leprosy Lepromatous 22 weeks af ter treatment.

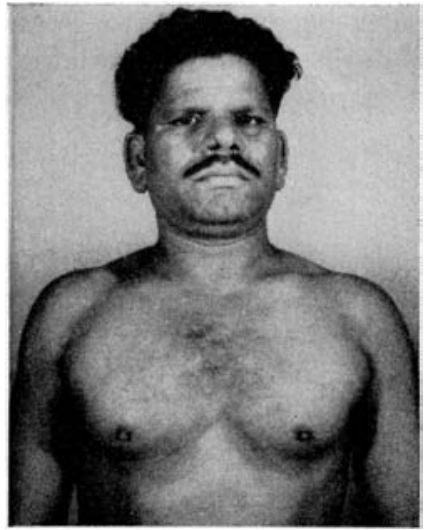

FIG. 6

Leprosy Lepromatous I 8 weeks after treatment.

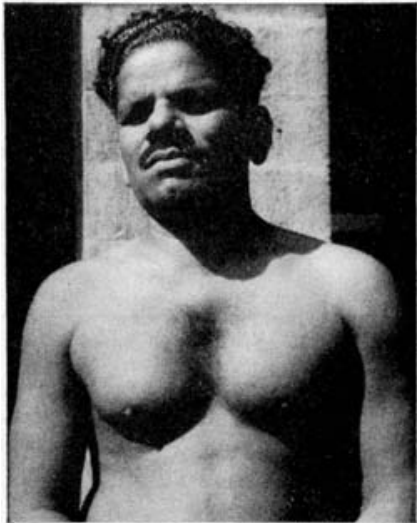

Fig. 9

Leprosy Lepromatous 33 weeks after treatment. 
3 months, but the bacteriological improvement remained fluctuating. Three patients showed good results, hypopigmented patches became partially pigmented in 4-6 months, infiltration regressed considerably in 3-5 months and bacteriological modification occurred in 4 months, but the macular patches were not affected. One patient developed a reaction when on a dose of 2 tablets ( $\mathrm{I}$ g.) a week; the reaction became persistent and the drug had to be stopped.

\section{Group B}

Out of the 4 patients, 2 patients who were on sulphone treatment for 8 months to 2 years started showing appreciable change in infiltrative lesions in 2 months after sulphonamide treatment. Erythema disappeared and the patches became flush with the normal skin in 6 months when bacteriological modification and improvement also became evident. One patient who had developed lepra reaction with $\frac{1}{2}$ cc. of sulphetrone developed a similar reaction with I tablet ( 0.5 g.) of Sulphonamide and the other developed a reaction when 2 tablets ( I g.) a week were given; the treatment in these cases had to be interrupted.

Bacteriological evolution (see Table I). Skin Scrapings

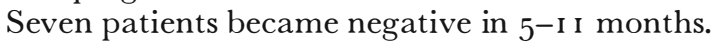
Considerable improvement with modification of bacilli was found in 7 patients. Three patients who had become negative were put on Sulphetrone $\frac{1}{2}$ cc. bi-weekly but they reverted to positivity after $2-3$ months.

\section{Tuberculoid leprosy}

The results are summarised in Table II. Clinically 6 patients of Group $A$ showed good response; the first sign of improvement was noticeable by the ushering in, as it were, of

TAB L E II

\section{Tuberculoid Leprosy}

Groups $A$ and B

\begin{tabular}{|c|c|c|c|c|}
\hline \multicolumn{5}{|l|}{ Group $A$} \\
\hline Patient & Duration of & & Total & Clinical \\
\hline No. & treatment & & dosage & response \\
\hline I & I67 days & & $3^{2} \mathrm{~g}$. & good \\
\hline 2 & I 20 days & & $24 \mathrm{~g}$. & good \\
\hline 3 & 95 days & & $20 \mathrm{~g}$. & good \\
\hline 4 & 90 days & & I $5 \mathrm{~g}$. & moderate \\
\hline 5 & I53 days & & $30 \mathrm{~g}$. & good \\
\hline 6 & 30 days & & I $3 \mathrm{~g}$. & moderate \\
\hline 7 & I 20 days & & $23 \mathrm{~g}$. & moderate \\
\hline 8 & 45 days & & IO g. & poor \\
\hline 9 & I 28 days & & $24 \mathrm{~g}$. & poor \\
\hline Io & I 52 days & & $30 \mathrm{~g}$. & poor \\
\hline I I & I9o days & & $40 \mathrm{~g}$. & poor \\
\hline 12 & 90 days & & $\mathrm{I} 8 \mathrm{~g}$. & good \\
\hline I3 & I6o days & & $36 \mathrm{~g}$. & good \\
\hline 14 & I 24 days & & $24 \mathrm{~g}$. & $\begin{array}{l}\text { no appreciable } \\
\text { improvement } \\
\text { (poor) }\end{array}$ \\
\hline \multicolumn{5}{|l|}{ Group B } \\
\hline I 5 & I 53 days & & $30 \mathrm{~g}$. & good \\
\hline I 6 & Ioo days & & $20 \mathrm{~g}$. & good \\
\hline I7 & 2 I 3 days & & $23 \mathrm{~g}$. & good \\
\hline \multirow[t]{3}{*}{ Group A: } & Good results & 6 patients & \multirow[t]{3}{*}{ Group B: } & \multirow[t]{3}{*}{ Good results 3 patients } \\
\hline & Moderate & 3 patients & & \\
\hline & Poor & 5 patients & & \\
\hline
\end{tabular}


pigmentation at the periphery of the hypopigmented patches in 8-Io weeks and the regression of infiltration started in $12-16$ weeks when the partial return of superficial sensations in the anaesthetic patches was also detectable. Nerve tenderness started improving in 8-1o weeks and disappeared completely in 5 months, but the thickening persisted till the end of the trial. Return of superficial sensation was not complete, as the residual anaesthesia remained unchanged in the centre of the patches. Three patients showed a moderate response. In these there was a partial and patchy return of pigmentation in some of the patches and there was the regression of infiltration. There was no improvement in the vasomotor discolouration of the hand in two patients and the improvement in anaesthesia was doubtful.

Five patients showed a poor response in 3 months. Their treatment could not be continued beyond this period due to certain administrative difficulty.

\section{Group B}

In Group B three patients who had shown no improvement in hypopigmentation, infiltration or erythema, for $4^{-6}$ months with sulphones began to show appreciable and impressive changes within 2 months of instituting Ro 4-43 93 and in 5 months the patches flattened out, erythema disappeared and the sensations returned to an appreciable degree and the colour of the patches returned to near normal. This may have been due to the drug substitution.

\section{SIDE EFFECTS}

On the whole the drug was well tolerated by the majority of the patients. One patient when on 3 tablets ( $1 \cdot 5$ g.) developed a generalised rash without affecting the lesions of leprosy; the rash disappeared on stopping the drug for a few days; it did not recur with 2 tablets (I g.) a week. This rash might have been a drug eruption. Another patient complained of intense itching and burning sensations all over the body which disappeared when the drug was stopped for a few days and did not recur with further treatment. Two patients developed lepra reaction and 2 developed erythema nodosum type of reaction which were under control by chloroquin or chloromycetin. In these patients the drug had to be stopped. In no case was there any adverse effect on blood count or $\mathrm{Hb} \%$.

\section{DISCUSSION}

The number of cases included in this trial is too small, and the duration of the treatment too short to make a definite and final assessment of the therapeutic efficacy of this drug in leprosy, but in view of the excellent therapeutic results obtained in a large number of cases combined with good tolerance and ease of administration, Ro 4-43 93 (FAnAsil 'Roche') should occupy a prominent position among the anti-leprosy drugs available today. Further extensive investigations are required to make a comparative assessment with other anti-leprosy drugs. In some of our patients the results have been superior to those obtained with sulphones and this observation has also been reported by Wilkinson, F. F. et al (I96I). During the trial we also observed that the drug has a quicker effect on the infiltrative than on the macular lesions of leprosy. Although we have not been able to work out critically the optimum dose schedules, yet we have gained the impression that 2 tablets ( $\mathrm{I}$ g.) a week is an adequate dose for clinical and bacteriological improvement and that 3 tablets a week do not produce any accelerated improvement. It may be possible at a later date to increase the interval even more, so as to arrive at a monthly administration regime of the drug.

The mechanism of repigmentation remains obscure but is interesting and is food for thought and further research. It may be possible that the drug in some way brings about some changes in the enzyme system which is connected with the process of pigmentation.

\section{SUMMARY}

34 leprosy patients, I 7 lepromatous and I 7 tuberculoid were subjected to a therepeutic trial with a long-acting Sulphonamide Ro 4-43 93 (FANASIL 'Roche') for a period of 22 months.

Of the I 7 lepromatous leprosy patients, Io patients showed excellent results, of these in 3 patients the improvement was spectacular as seen in the photographs. Two patients with lepra reaction and 2 patients with erythema nodosum type of reaction were encountered.

Three patients showed good results. Of the 
17 tuberculoid leprosy patients, I4 had no treatment previously. Out of these I 4 patients, 6 patients showed good response, 3 moderate response, and 5 poor response in 3 months of treatment, whereas 3 patients which were previously treated with sulphones and had become static clinically, showed impressive improvement in 2 months after sulphonamide therapy.

Skin eruption was encountered in two patients. However, in both it disappeared after interruption of treatment and did not recur on readministration of the drug.

\section{GONGLUSION}

I. Ro 4-43 93 (FAnAsil 'Roche') has an indisputable activity in the treatment of leprosy.

2. The drug is well tolerated and easy to administer.

3. Lepra reactions are not frequent with this drug, but all the same it is capable of producing lepra reaction or erythema nodosum type of reaction in those who develop a similar reaction with other anti-leprosy drugs.

4. Two tablets ( I g.) a week appears to be an adequate dose.

\section{AGKNOWLEDGMENT}

We thank Messrs Roche Products Limited, Bombay, for the generous supply of the drug "FAnAsil 'Roche", (Sulphonamide Ro 4-43 93) for this trial and their help to carry out this investigation.

\section{REFERENCES}

GAIND, M. L. and soHi, A. s. (I964) Preliminary Report on Trial with Sulphadimethoxine (Madribon) in Leprosy Armed Forces Medical Journal, 20, (I) I 2-i 9.

GARCIA HERRERA, E. (I964) Un nuevo sulfamidico de acción therapeutica continua. Medicina, (Mexico), 44, (93 I), 8-i 8 .

OpRomolla, D. v. A., et al. (1964) The Treatment of Leprosy with New Long-acting Sulf onamide. Presented at the ist International Congress of Tropical Dermatology, Naples, 8-i 5 June

BARClAy, A. c. et al. (1963) Therapeutica de la lepra con el Preparado Ro 4-43 93. Presented at the 8. Internat. Congress on Leprosy, Rio de Janeiro, 1963.

GHOSh, s. and chakraborty, в. к. (I 964) Ro 4-43 93 - A long-acting sulphonamide in treatment of leprosy: Preliminary report. Bull. Calcutta School of Trop. Med. 12, (I) 33 .

Wilkinson, F. F. et al. (i96I). La Sulfadimetoxina en al Tratamiento de la lepra; Resultados al año de observación Leprologia, 6, (2) I 92, Buenos Aires.

Tschudi-madsen, s. (1 964) Serum Concentration and Antibacterial Activity of 4-Sulfanilamido-5, 6-dimethoxypyrimidine Amer. 7 Med. Sci., 247, 2 I 7-22. 